\title{
Study of Surface Quality after Turning of Steel AISI 304
}

Ján Duplák, Jozef Zajac, Michal Hatala, Dušan Mital', Miroslav Kormoš,

Technical University of Košice, Faculty of Manufacturing Technologies, Bayerova 1, Prešov 080 01, Slovakia. Email: jan.duplak@tuke.sk

Accurate and effectively machining of steel class AISI is in the fact of its chemical composition and mechanical properties often a significant problem. Effort to preserve the economical efficiency of whole production process is necessary to have behavior of the cutting tools in the process of machining these steels. Food industries all over the world use this type of steel as a basic construction material of machines and equipments designed for this type of industry. Ability to consistently know these steels is the way how to effectively machining. Small and medium manufacturing enterprises not have the means to experiment with this material and wasted, because it belongs to more expensive. For this reason in order to create high-quality machined surface while minimizing defects of products in production is significantly increased time of machining and producing product from this steel is economically inefficient. Paper deals with study of surface quality after machining of steel AISI 304. Outputs of realized experiment should help to small and medium companies to improve knowledge of steel AISI and its machining and also better understand how to effectively and profitably produce products of these steels.

Keywords: AISI 304, roughness, surface, turning.

\section{References}

[1] ČEP R., et. al. (2010). Ceramic cutting tool tests with interrupted cut simulator, pp. 144-148. In: IN-TECH 2010: Proceedings of International Conference on Inovative Technologies: Praha: 14. - 16. 9.2010. - Jaroměř ISBN 97880-904502-2-6.

[2] ČUMA, M., JANAK. M. (2009). The impact of cutting fluids on machining, p. 25-30. In: ICPM 2009. - Prešov FVT TU, ISBN 9788055302430

[3] DUPLÁK, J (2010). T-vc dependence for cutting ceramic in standard ISO 3685, p.58-62, In: Manufacturing Engineering. Vol. 9, N. 4 (2010), ISSN 1335-7972

[4] DUPLÁK, et.al. (2010). T-Vc Dependence for sintered metal in standard ISO 3685, p. 6-9. In: Technological enfineering, Vol. 7, N. 2 (2010), ISSN 1336-5967

[5] MICHALIK, P., ZAJAC, J. (2010). Intelligently programming of holes machining, p.63-65, In: Manufacturing Engineering, No.4, Vol. IX, ISSN 1335-7972

[6] SOMŠÁKOVÁ Z., et.al. (2012). Machining of Wood Plastic Composite, p.55-57, Materialeplastice, No.1, Vol. 49, January 2012, ISSN 0025-5289

[7] VASILKO K., (2007). Analytical theory of splinter machining, p. 338, Prešov FVT, ISBN 978-80-8073-759-7

[8] ZAJAC J., et.al. (1995). Cutting facilities of new type of came cutting material, p. 138- 139, In: Proceedings of the conference PPTO, Košice. 